Published on Reviews in History (https://reviews.history.ac.uk)

\title{
Intimate Violence: Anti-Jewish Pogroms on the Eve of the Holocaust
}

Review Number: 2302

Publish date: Thursday, 17 January, 2019

Author: Jeffrey S. Kopstein

Jason Wittenberg

ISBN: 9781501715259

Date of Publication: 2018

Price: $£ 23.99$

Pages: 192pp.

Publisher: Cornell University Press

Publisher url: http://www.cornellpress.cornell.edu/book/?GCOI=80140102719170

Place of Publication: Ithaca, NY

Reviewer: Jan Burzlaff

Today it seems almost customary to apologise for writing another book on the events between 1941 and 1945 that came to be known as the Holocaust, Shoah, or the Genocide of the Jews.(1) The explosion of scholarship since the late 1980s has filled entire libraries with information on the Holocaust and established a basic chronology. Mass shootings, the misery of ghettos and camps and gas were the primary killing methods. When historians delve into the Holocaust, such writing involves critical actors, though the focus has shifted from Hitler?s 'gang' (Franz Neumann, 1942) to 'ordinary men' (Christopher R. Browning, 1992) and, for over a decade now, women. Various explanations of the Holocaust's origins and implementation have appeared, including modernity, imperialism, colonialism, state destruction, sadism, nationalism and deep-rooted antisemitism.(2) Intimate Violence is intriguing and adopts a new approach. Written by Jeffrey S. Kopstein and Jason Wittenberg, two political scientists teaching at the University of California at Irvine and Berkeley, it stands out in its methodology and object - pogroms occurring in the western borderlands of today?s Poland, Ukraine and Lithuania during the summer of 1941. Since the emergence of the field of Holocaust studies, political scientists and sociologists have offered innovative research. One remembers the late Raul Hilberg, Zygmunt Bauman, Jan T. Gross or, more recently, Daniel J. Goldhagen, though the polemic that his book Hitler?s Willing Executioners stirred has proven unrepresentative for the usually fruitful dialogs between both academic disciplines.(3) However, the last generation of political scientists has been somewhat reluctant to address the Holocaust. Perhaps, as Charles King suggested in 2012, the question of the ?uniqueness? of the events has prevented scholars from tackling vital questions of wartime occupation and its complex relationship to violence, local resistance and genocidal policymaking.(4) Thus, we should applaud the fact that along with Evgeny Finkel?s 2017 monograph on the survival strategies of Ordinary Jews, Kopstein and Wittenberg took an initiative with this critical, interdisciplinary step toward a subtler understanding of the origins of communal violence.

Jan T. Gross?s 2001 study Neighbors about the Jedwabne massacre on 10 July 1941 has fundamentally changed how scholars write about pogroms during the Holocaust. Shortly after Nazi Germany launched Operation Barbarossa and invaded the Soviet Union, in a zone that had been occupied by both regimes, the small town of Jedwabne near ?om?a saw the Poles drowning and hunting down their Jewish neighbours before dragging a sizeable portion - several hundred - into a barn, which was then set aflame.(5) This 
staggering re-evaluation of the Polish involvement in the wartime murder of Jews provoked a wave of shock throughout the country. Many Poles had become numb to the sufferings of other ethnicities - such as the Jewish fate, which, they feared, would largely conceal their own martyrdom - as a result of the Soviet education that hid local involvement in the Holocaust and saw crystallised evil in Nazi Germany alone. Despite many critical reviews and acrimonious attacks on the part of skeptical readers and pseudohistorians - consider the recent revival of Polish right-wing nationalism - Jan T. Gross's appalling account still stands. The book under review must be understood as an effort to position his findings within a longawaited comparative perspective. The authors place Jedwabne within an intense wave of pogroms that occurred during the summer of 1941. Kopstein and Wittenberg argue that Jedwabne is a tragic fragment of a larger phenomenon of communal violence rooted in the political landscape of the interwar years. In 219 towns in Eastern Poland, Western Ukraine, Lithuania and Romania, inhabitants violently turned against their Jewish neighbours between June and late July of 1941. In areas torn by quickly changing political allegiances and hastily abandoned by the Soviet state apparatus but not yet entirely under Nazi control, pogroms had a strong connection, Kopstein and Wittenberg argue, with interwar political behaviour. The pogroms, understood as neighbour-on-neighbour violence, can be explained, they convincingly demonstrate, by local politics that tended to suppress Jewish claims for political representation and national rights. In the context of the strong revival of Polish ethno-nationalism after the Soviets had left these western borderlands, pogroms occurred in which non-Jewish inhabitants oppressed those they thought would be their future political rivals.

The question of the origins of these brutal events runs throughout this short but important monograph. Its approach is consistent with current debates on micro-conflicts in the social sciences, with which historians have only timidly engaged as of yet. Most historians still tend to neglect, if not forget, the political antecedents of wartime events in general accounts and textbooks of the multiple places, people and events involved in the Holocaust. Why did pogroms occur in these places? In their refreshing analysis, Kopstein and Wittenberg establish lines of continuity between the inter-war period and 1941 and review the political struggles that had taken place since the creation of the Polish state in 1918. The authors draw on the Polish censuses of 1921 and 1931, including information on ethnic and religious identity, as well as levels of literacy. To illustrate the political landscape, Kopstein and Wittenberg refer to the elections of 1922 and 1928. They investigated these elections at the municipal level, which yielded votes for 22 parties, including eight internally divided Jewish parties. Whatever historians may think of the lenses with which the authors read the database comprising over two thousand localities in six provinces (voivodeships), its creation should be applauded.(6)

Brandishing an ethnolinguistic-Christian ideal of Polishness and spurred on by the charismatic Roman Dmowski (1864-1939), the National Democrats (Endecja) called for a unified state composed of Poles alone. In the face of their Darwinian beliefs regarding competing races, the national consensus set up by dictator Marshal Józef Pi?sudski (1867-1935), along with the Non-Party Bloc for Cooperation with the Government (Bezpartyjny Blok Wspó?pracy z Rz?dem), accommodated ethnic minorities in exchange for their allegiance to a state led by Poles. The authors make it clear that multiple languages, cultures and ethnicities were increasingly divided by political tensions during the 1920s. In addition to almost five million Ukrainians and two million Belarusians, three million Jews, mostly in the urban Eastern borderlands, felt deeply underrepresented in Parliament and overruled by a lack of autonomous institutions, let alone a Jewish National Council. The Zionist, Revisionist Zionist - under the leadership of Vladimir (Zev) Jabotinsky - and Bundist organisations were all rooted in Jewish nationalism, called for a Jewish state in Palestine or, in the case of the Bundists, a Yiddish nation in Poland.

As Kopstein and Wittenberg demonstrate in subsequent chapters, pre-existing ethnic tensions exploded when the Soviet occupiers established their political rule. Beyond the electoral statistics and the two censuses, the authors delve into survivor memoirs from the Emanuel Ringelblum Jewish Historical Institute, Warsaw, collected between 1945 and 1947, and the Yizkor books representing Jewish wartime memories. As a dramatic break with the past, the new regime wished to quell Polish nationalism (as undesired as any other form of nationalism) in the Soviet state and removed Poles from posts of responsibility. For instance, 
drawing on previous calculations, the authors reveal that among the 9,000-12,000 people working in the state administration in the Bia?ystok region, fewer than 3,000 were Polish (p. 60). Once the Soviet authority collapsed due to the Nazi invasion, most of the pogroms occurred during a six-week period beginning on 22 June 1941. Unleashed by dissipating legal restraint and sometimes, but not always, incited by the Germans, the perpetrators concentrated, Kopstein and Wittenberg argue, not on the prior collaborations between local Jews and the Soviets but on the role Poles feared those Jews would play in the future political landscape (p. 57). Here, the authors build on the power-threat theory. First applied to the lynching of African-American men, it holds that in places where minority groups threaten the dominance of majority groups, the majority will take action.(7) It is true that too often, ethnic violence has only been explained by state-led violence and the importance of old or new elites. Yet in the summer of 1941, as the authors rightly demonstrate, the Nazi and local elites were only in the making. As a result, several conditions necessary for a pogrom emerge from Kopstein?s and Wittenberg?s painstaking efforts to create and analyse this extensive database. First and foremost, the size of the local Jewish community mattered. Pogrom localities had more than ten times as many Jewish inhabitants as non-pogrom localities. Equally important were the Jewish call for cultural and political representation and the popularity of parties that favoured interethnic dialog, such as the so-called Bloc of National Minorities and the Galician Zionists. Pogroms occurred in places where the perceived threat of and the longing for an ethnically homogenous state were higher, rather than where there was widespread approval of parties engaging in ethnic tolerance and national equality for Jews. The analysis concludes on firm correlations between electoral behaviours, the perceived threat of an ethnic minority, the demographic weight of the latter and political integration and exclusion during wartime. In those towns where pre-war political polarisation existed, state collapse and war increased ethnic tensions, reopened old sores and brought about pogroms.

The arguments are mostly convincing because the authors emphasise political integration, a notion misrepresented by historians, in understanding pogroms. As a side note, the book's subtitle, On the Eve, somewhat misleads the reader by suggesting that pogroms were not an integral part of the events that historians generally group under the term 'the Holocaust'. Whatever one?s stance on the timeline of the ?Final Solution' may be — between June and December of $1941 \underline{(8)}$ — the gruesome events depicted here belong to the Holocaust.

The book poses many fascinating questions, some of which I wish to address in my capacity as a historian. The heated context of racial and nationalistic ideas that led, in the summer and fall of 1941, to 'generative violence', to use Max Bergholz's term, is not new for historians of Central and Eastern Europe.(9) However, such historians have focused on nationalism related to Nazi colonialism, not the origins of pogroms. The political character of the latter, as the authors show, reveals how perilous nationalism and nation-building can be when wartime allegiances and lowered moral sensibilities are combined with an us-against-them mentality. Yet ethnic violence did not have to be an element of wartime life, even in relationships as problematic as those between Jews and non-Jews in Poland. The relationship between political integration and pogroms allowed for a wide range of variations across occupied Poland. If you lived, as a Jew, in a small town with an even smaller Jewish community, minimal political mobilisation for Zionists and Bundists and only a few inhabitants voting for the Nationalists (Endejca), your chances of avoiding a pogrom were relatively high. Perhaps, in places where such violence did occur, we historians have underestimated the power of de-centralised and bottom-up violence that appears to be unorganised, which historians prefer to explain via somewhat atemporal categories such as seemingly centuries-old antisemitism. As Kopstein and Wittenberg show, these cases of intimate violence display, to say the least, certain patterns. Classic studies such as Christopher R. Browning?s Ordinary Men demonstrated that the reasons for killings are situational rather than cultural. Why not apply this framework to pogroms and other understudied cases of substate violence, such as the activities of Soviet partisans or armed resistance against the Nazi occupiers? $\underline{(10)}$

Two complementary paths are thus open for historians of today. On the one hand, the state certainly did matter in the Holocaust, particularly its collapse in the areas of ?double occupation? (Timothy Snyder). Those were the bloodlands, where most of the killings fields were to be found, and the book is consistent with Snyder?s findings: state collapse allowed for the pogroms. On the other hand, regarding the small 
Ukrainian town of Buczacz and Jews in and around ghettos, Omer Bartov and Evgeny Finkel recently illustrated how much small-scale studies with concerns far removed from state-centered actions and direct Nazi orders can help answer questions of violence, resistance and survival.(11) The book under review speaks to both of these historiographical trends.

Furthermore, the legacy of Jan T. Gross looms large. Most communities (91 per cent) never experienced a pogrom, most Poles never attacked their neighbours. One thorny question in Gross's study focused on the representativeness of Jedwabne within Nazi-occupied Poland. Gross once wrote that 'there is no reason to single out Jedwabne as a place where relationships between Jews and the rest of the population during those twenty months of Soviet rule were more antagonistic than anywhere else'.(12) At most, he specified a strong Polish conspiracy against the Jews and the shocking cruelty of the local Soviet Secret Police (NKVD). While following Gross in stressing Jedwabne?s extraordinary cruelty, Kopstein and Wittenberg demonstrate that the town was more politically polarised than most other localities. Unusually for the region, the town was devoid of a Belarusian minority, which left Poles and Jews face-to-face. Here, as in other towns, Poles had been more than a third likelier to vote for the nationalist Endecja.

In my opinion, the chief merit of the book lies in the refutation of certain persistent arguments that historians have advanced regarding the pogroms.(13) Economic reasons, supposedly innate Polish anti-semitism and ethnic differences cannot account for their occurrence. As Kopstein and Wittenberg point out, looting is different from killing for the sake of looting. What scholars have termed the 'myth of Judeo-Bolshevism' (? ydokomuna), that is, presumed Jewish involvement in communism, is not reflected in either the electoral results or in the censuses.(14) There is no observable relationship between inter-war votes for communist parties and the outbreak of pogroms. If pogroms were merely retaliation against Jewish-Soviet collaboration once the local Party officials and their administrations had left, other 'collaborators' would also have been targeted. All this does not deny that perpetrators may have had these ideas in mind when they committed and, later, attempted to justify their crimes. This also does not deny that anti-semitism was widespread among Poles and other ethnicities, but no factor can account for these events alone.

In a book with such ambitious goals and a bold interdisciplinary focus, any critique lends itself to a suggestion. To be sure, the most irritating aspects of this book for historians will be the big data used and the systematic explanation based on levels of political integration. This is a rather common distinction between the two disciplines: historians are, by training, keen on historical contingency and details. Can the election results of 1928 account for events more than a decade later? Comparative politics has shown that voting preferences may change quickly, and 1928 was a somewhat calm year for Polish Jews. One could also argue that Pi?sudski?s inclusive politics held antisemitic votes at bay until 1935. Furthermore, Kopstein and Wittenberg admit that they 'are not able to account for all the spatial variation of pogrom occurrence, nor do the numbers give us a concrete understanding of how the social and political background created the facilitating conditions for pogrom occurrence, how the pogroms unfolded, and why they sometimes did not occur even though they "should" have'. Rather than a fault of the book, this admission is an invitation for scholars to work more closely together (e.g. on Lithuania, p. 117). How many victims were killed in these 219 pogroms? Did a certain threshold exist, a level at which radicals' calls for violent acts led to murder? How and when did eager nationalists convince their fellow inhabitants to commit murder? Here, the main weakness of the book?s explanation appears: why were women and children killed when the most politicised inhabitants targeted first and foremost those Jewish citizens they believed would soon wield power over them? One would need to dwell far more on the actual process of the disintegration of the social tissue. To consider the opposite question, why and when did the murder stop? Why and how did the 1941 pogroms differ from the deadliest pogrom wave, which struck Poland in 1918-1920?

The greatest confusion for historians may arise from the absence of the Nazis in the analysis, following their minimal role in Gross's Neighbors. Similarly, one would expect the authors to use the notion of cultural assimilation as an analytical tool, which Jewish studies, in particular, have emphasised since the 2000s. The argument regarding Orthodox Jews as the most visible targets who yet often avoided pogroms is well taken (p. 131), but I wonder to what extent assimilation may have saved lives through moral and communal 
solidarity. The presence of Nazi officials may have also incited locals to eagerly endorse their new masters, especially those who had survived NKVD prisons. Complementary research in German archives would confirm or modify these various episodes and reveal local points of juncture.(15) Regarding Jewish voices, it is regrettable that the authors did not include, as they admit, certain video testimonies from the USC Shoah Foundation. These could help us understand more clearly, at the local level, the settings of cultural assimilation and add the voices of survivors, which often disappear behind the numbers.(16) To be sure, this is an analytical book, not a narrative.

In the midst of the fiery reception of Neighbors, Jan T. Gross stated that the very nature of Holocaust studies consists of asking additional questions rather than accepting simplistic answers.(17) In this sense, Kopstein and Wittenberg have offered an excellent outline for more research. It is an innovative and elegant book. Given the violence that Neighbors provoked in 2001 (and Jan Grabowski's Hunt for Jews in 2010), one can only congratulate Kopstein and Wittenberg for their courage in having continued to study the bloody summer of 1941. In the end, their thought-provoking analysis reminds us that respect for historical facts and the freedom of scientific research are not a part of the natural work environment, at least not in today?s Poland, which wallows in competitive suffering. One can only hope that original research, as illustrated in this book, may continue elsewhere.(18)

\section{Notes}

1. For the use of the different terms, see Andrew I. Port, 'Holocaust Scholarship and Politics in the Public Sphere: Reexamining the Causes, Consequences, and Controversy of the Historikerstreit and the Goldhagen Debate: A Forum with Gerrit Dworok, Richard J. Evans, Mary Fulbrook, Wendy Lower, A. Dirk Moses, Jeffrey K. Olick, and Timothy D. Snyder', Central European History, 50, 3 (2017), 375-403. Back to (1)

2. A full panorama would be a monograph in itself. The array includes books by Donald Bloxham, Ju?rgen Zimmerer, Timothy Snyder, Saul Friedla?nder, Christian Gerlach, Omer Bartov and others. Back to (2)

3. Daniel J. Goldhagen, Hitler's Willing Executioners (New York, NY, 1996). For the implications see Norman G. Finkelstein and Ruth B. Birn, A Nation on Trial (New York, NY, 1998); and The Goldhagen Effect: History, Memory, Nazism - Facing the German Past, ed. Geoff Eley (Ann Arbor, MI, 2000).Back to (3)

4. Charles King, 'Can there be a political science of the Holocaust?', Perspectives on Politics, 10, 2 (2012), 323-41.Back to (4)

5. Jan T. Gross, Neighbors: The Destruction of the Jewish Community in Jedwabne, Poland (Princeton, NJ, 2001). The book was reviewed in this journal by John Klier < https://www.history.ac.uk/reviews/review/306> [2] [accessed 12 November 2018]. For an insightful review of subsequent Eastern European scholarship, see Joanna Michlic, Coming to Terms with the Dark Past': The Polish Debate about the Jebwabne Massacre (Jerusalem, 2002), and Marci Shore, 'Conversing with Ghosts: Jedwabne, Z?ydokomuna, and Totalitarianism', in The Holocaust in the East: Local Perpetrators and Soviet Responses, ed. (Pittsburgh, PA, 2014), p. 5-28. Back to (5)

6. The six voivodeships are Bia?ystok, Polesie, Volhynia, Lviv, Stanis?awów and Tarnopol.Back to (6)

7. Hubert M. Blalock, Toward a Theory of Minority-group Relations (New York, NY, 1967).Back to (7)

8. Scholars do not agree on the exact timeline. Christopher R. Browning, The Origins of the Final Solution: The Evolution of Nazi Jewish Policy, September 1939-March 1942, (Lincoln, 2003), p. 85ff. sees the decision made by Hitler to exterminate all Jews in the euphoria of looming victory in the fall of 1941. Christian Gerlach, The Extermination of the European Jews (Cambridge, 2016), p. 66ff. argues for somewhere in early December after the Soviet counterattack at the gates of Moscow, while Peter Longerich, Holocaust: The Nazi Persecution and Murder of the Jews (Oxford, 2010), p. 179ff. views it as an incremental process until spring 1942. Back to (8)

9. See for instance Max Bergholz, Violence as a Generative Force: Identity, Nationalism, and Memory in a Balkan Community (Ithaca, NY, 2016). For inter-war Poland, integrated into the book?s analysis, see Stephanie Zloch, Polnischer Nationalismus. Politik und Gesellschaft zwischen den beiden Weltkriegen 
(Cologne/Weimar, 2010), and, not cited, Stephan Lehnstaedt, Imperiale Polenpolitik in den

Weltkriegen. Eine vergleichende Studie zu den Mittelma?chten und zu NS-Deutschland (Osnabrück,

2017).Back to (9)

10. War in a Twilight World. Partisan and Anti-Partisan Warfare in Eastern Europe, 1939-45, ed. (New York, NY, London, 2010). Back to (10)

11. Timothy Snyder, Black Earth: The Holocaust as History and Warning (New York, NY, 2015), p.117-44 and p.182ff., <https://www.history.ac.uk/reviews/review/2036> [3] [accessed 12 November 2018]. For the first attempt to integrate statelessness, see Dietrich Beyrau, Schlachtfeld der

Diktatoren. Osteuropa im Schatten von Hitler und Stalin (Göttingen, 2000); Omer Bartov, Anatomy of a Genocide: The Life and Death of a Town Called Buczacz (New York, NY, 2018), p. 129-244;

Evgeny Finkel, Ordinary Jews: Choice and Survival During the Holocaust (Princeton, NJ, 2017). It is telling that all four historians begin their analysis with the inter-war years. Back to (11)

12. Jan T. Gross, Neighbors, op. cit., p. 43. Back to (12)

13. For an overview (not cited in the bibliography), see Juifs et Polonais 1939-2008, ed. Jean-Charles Szurek and Annette Wieviorka (Paris, 2009).Back to (13)

14. For an evaluation, see now Paul A. Hanebrink, A Specter Haunting Europe: The Myth of JudeoBolshevism (Cambridge, MA, 2018). The authors do not quote the first debunk of the 'myth of JudeoBolshevism' by Henryk Grynberg, 'Zycie jako dezintegracja', in Prawda nieartystyczna (S?kowa, 1984), p. 19-22; nor the important Joanna Tokarska-Bakir, '?ydzi u Kolberga', in Rzeczy mgliste. Eseje $i$ studia (Sejny, 2004), 66-7, who already expressed doubts about the switch, during the war, from an old-fashioned and religious antisemitism to a new racial version of it.Back to (14)

15. A promising starting point could be, for instance, the famous letter of 'Franzl', first debunked at the exhibition on the Wehrmacht in 1995. The soldier described to his loved ones left in Vienna, Austria, some of the Nazi atrocities, the massacres of Ukrainians by the NKVD and the local pogroms by Nazis and Poles. Federal Archives Freiburg (BA/MA), RW 4/V. 442A, 202.Back to (15)

16. For the latest historical writing on the Kishinev pogrom on April 19 and 20, 1903, see Steven J. Zipperstein, Pogrom: Kishinev and the Tilt of History (London, 2018), which complements the literature on Russian pogroms that the authors cite p. 120-2.Back to (16)

17. Jan T. Gross, 'A Response', Slavic Review, 61, 3 (2002), p. 483.Back to (17)

18. The study of how Italians turned on their Jewish neighbours and betrayed them between 1943 and 1945 is the object of Shira Klein, Italy's Jews from Emancipation to Fascism (Cambridge, 2018) and Simon Levis Sullam, The Italian Executioners: The Genocide of the Jews of Italy (Princeton, NJ, 2018). Back to (18)

Source URL:https://reviews.history.ac.uk/review/2302

\section{Links}

[1] https://reviews.history.ac.uk/item/300428 [2] https://www.history.ac.uk/reviews/review/306\&gt;

[3] https://www.history.ac.uk/reviews/review/2036\&gt; 